\title{
Entigheioungen des
}

(Wber $=$ Seeamts und der Seeämter des

Deutidhen Reidhs.

Ģerausgegeben

im

Reichsamt des Inmern.

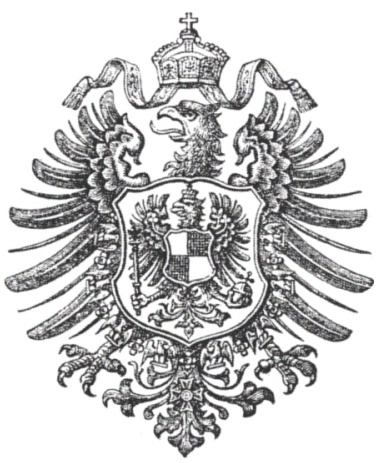

$\mathscr{Z}$ diter $\mathfrak{B}$ and.

Geft 1.

\section{Gamburg.}

Drut und Derlag von 5 . friederidien \& $\mathbb{C}_{0}$.

1888. 